\title{
Impact of Stem Education on Academic Achievement of Elementary School Students' of Delhi
}

\author{
Megha Chaudhary, Gyanendra Nath Tiwari, Sujeet Kumar
}

\begin{abstract}
STEM education does not follow traditional teaching methods but is based on interesting and critical thinking activities. It is important to increase students' interest and awareness of STEM educational activities to encourage them to learn STEM. STEM-based education can help students or children learn and participate in activities based on real-life experiences. We need to let them know that what they learned in STEM today is not only building their own future, but also the cornerstone of the country.

Since no study has been done to know the difference in the academic achievement and basic attitude of the students towards this approach based on gender school types (government and private); before and after the conduction of STEM programme this study will give STEM practitioners strategies to design and integrate STEM content purposefully for the students; so that students can develop a positive attitude towards STEM programme which will in turn help them to acquire higher academic achievement and make study more effective. This study will also through light on the teachers to make STEM programme more effective. This study will also be of immense help to the school authorities while opting for better STEM programme.
\end{abstract}

Index Term: Blended learning, effective teaching, motivational skills, engaging classroom, better learning environment, STEM approach.

\section{INTRODUCTION}

STEM is an new and popular approach combining difficult concepts of academics with day to day life teachings; as students use STEM to connect between schools, communities, jobs, and global businesses. STEM literacy increases the tendency to stand in the fast-changing economy. (Tsupros, 2009)

STEM-based education is very important because it is evident and perceptible from all other perspectives in our lives. We are surrounded by scientific advertisements that touch every part of our lives in some way or another. Increasing use of technology has also become an integral part of our lives. Engineering is a broad area of designing bridges to roads and from the environment to houses. Mathematics exists in every department, business or industry, and even plays a vital role in our lives. STEM touches on all aspects of our economic and social life. By teaching STEM education and its concepts to students, there will be many opportunities for students from different industries.

Revised Manuscript Received on December 30, 2019.

* Correspondence Author

Megha chaudhary, Research Scholar (Ph.D), STEM Education, Amity University,Noida, India.

Dr. Gyanendra Nath Tiwari, Associate Professor, Amity University, Noida, India.

Dr.Sujeet Kumar, Associate Professor, department of education, Guru Ghasidas Vishwavidyalya, Bilaspur, Chhattisgarh, India.

(c) The Authors. Published by Blue Eyes Intelligence Engineering and Sciences Publication (BEIESP). This is an open access article under the CC BY-NC-ND license (http://creativecommons.org/licenses/by-nc-nd/4.0/)
There is a myth, STEM is difficult to learn, but if you teach passionately, you will succeed. STEM-based education can help students improve and enhance their analytical and reasoning skills because of their real-life experience and circumstances.

It combines multiple concepts into one to solve problems, helping them to see problems from a 360-degree perspective, find alternative solutions, and ultimately choose the most appropriate solution. This is also a brilliant career opportunity. It not only provides hands-on experience, but also opens up ideas for solving problems from different angles. It involves not only learning but also interesting learning.

\section{RESEARCH GAP}

From the global and local aspect many researches related to STEM program has been done but a research gap still exist as because literature review shows that no study has been done to know the difference in the academic achievement and basic attitude of the students towards this approach based on gender and school types (government and private) .A research gap has also been noticed related to the location of the study as because no studies has so far been done to access the effect of STEM on academic achievement of the elementary students of New Delhi. Hence a sincere attempt has been made by the researcher to fill the gap in these areas related to STEM.

\section{OBJECTIVES OF THE STUDY}

1. To know how STEM program, effect the attitude of elementary grade students differently for boys and girls.

2. To understand and calculate the variation in the academic achievement of Delhi students towards STEM program.

3. To calculate the significant distinctiveness in the attitude of elementary students towards STEM curriculum based on school types i.e private and government schools.

4. To know the difference in the academic and overall achievement of school students towards STEM pedagogy.

\section{HYPOTHESIS}

1. It can be stated that there is no remarkable distinctiveness in the attitude of students after the completion of the STEM programme in schools.

2. There is no variation in the achievement of elementary grade students towards this new STEM program based on gender of the students.

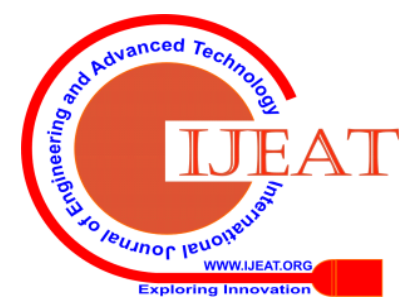


3. There is no significant distinctiveness in attitude of elementary students towards STEM curriculum based on school types i.e private and government schools.

4. There is no difference in the academic and overall achievement of school students towards STEM pedagogy.

\section{V.DELIMITATIONS} only.

1.This study was limited to elementary school students

2. The study was limited to class- 8 only.

3. The study was limited to attitude of the students only.

4. The study was limited to achievement of the students only.

5. The study was limited to science subject of the STEM education only.

6 . The study was limited to six schools viz. 3 government and 3 private schools only.

7. The study was limited to 300 samples viz. 50 students of each school only.

\section{RESEARCH DESIGN}

In this experimental research, a basic pre-experimental research design has been used. In this study, a set of pre-test-post-test research designs was used.

\section{VII.METHOD}

In this study, descriptive or normative surveys were used. In this study, a questionnaire survey was used.

\section{POPULATION}

In this study on STEM program all the elementary grade school students of Capital city New Delhi were considered as the target population.

\section{SAMPLING TECHNIQUES}

Systematic sampling or purposive sampling was done to select students from 6 elementary schools.

Stratified random sampling was done to choose two strata i.e government and private schools. After selection of the strata; Random sampling technique was conducted to select 150 samples from each strata.

Thus it can be said that random sampling technique was used in the present study to select the 300 actual sample.

After collection of the actual sample two categorizations are done:

\section{X.TOOLS USED}

i. Attitude Scale

ii. Achievement Scale/ Proficiency test

\section{RESULT}

Table 1. showing the distinctiveness in the attitude of students after the completion of the STEM programme in schools.

\begin{tabular}{|l|l|l|l|}
\hline $\begin{array}{l}\text { Groups } \\
\text { (VARIABLES) }\end{array}$ & Sample & Mean & t-value \\
\hline Male & 120 & 79.56 & 0.58 \\
\hline Female & 180 & 80.38 & \\
\hline
\end{tabular}

*Not significant .05level

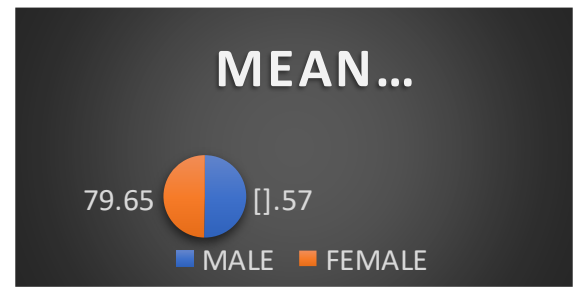

Fig 1 PIE chart showing the basic mean difference in the attitude of school students towards STEM pedagogy based on gender after (post-test) the conduction of STEM programme.

Table 2. Showing difference in the academic achievement of elementary grade students towards STEM curriculum on the basis of gender after (post-test) the conduction of STEM programme.

\begin{tabular}{|l|l|l|l|}
\hline $\begin{array}{l}\text { Groups } \\
\text { (VARIABLES) }\end{array}$ & Sample & Mean & t-value \\
\cline { 1 - 3 } Male students & 120 & 10.64 & 0.157 \\
\cline { 1 - 3 } Female students & 180 & $\mathbf{1 0 . 6 9}$ & \\
\hline
\end{tabular}

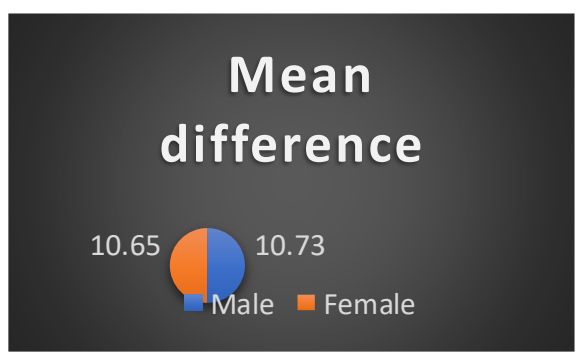

Fig II. Stating the variation in the academic achievement of school students towards STEM pedagogy on the basis of gender.

Table 3. Showing the significant distinctiveness in the attitude of elementary students towards STEM curriculum based on school types i.e private and government schools.

\begin{tabular}{|l|l|l|l|}
\hline $\begin{array}{l}\text { Groups } \\
\text { (VARIABLES) }\end{array}$ & Sample & Mean & t-value \\
\hline GOVERNMENT & 150 & 79.65 & \multirow{2}{*}{-0.18} \\
\cline { 1 - 3 } PRIVATE & 150 & 80.34 & \\
\hline
\end{tabular}

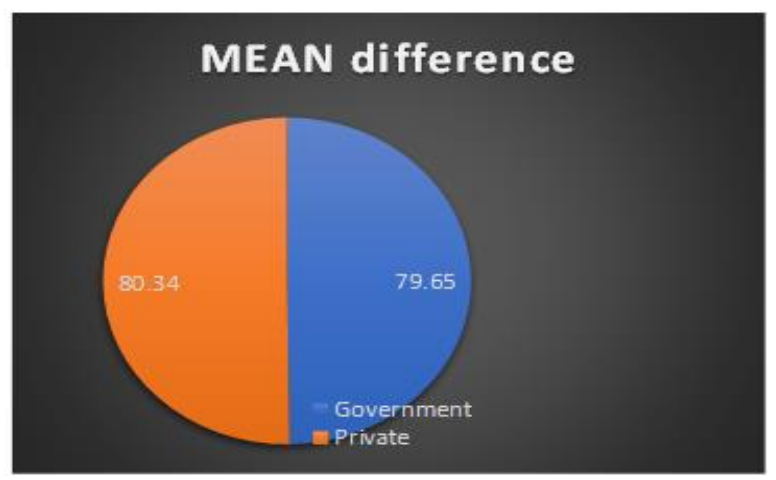

Fig III. depicting the Mean difference in the basic attitude of government and private elementary students after the conduction of STEM programme. 
Table 4. Showing difference in the academic and overall achievement of school students towards STEM pedagogy.

\begin{tabular}{|l|l|l|l|}
\hline $\begin{array}{l}\text { Groups } \\
\text { (VARIABLES) }\end{array}$ & Sample & Mean & t-value \\
\hline Government & 150 & 10.4 & -1.112 \\
\hline Private & 150 & 11.01 & \\
\hline
\end{tabular}

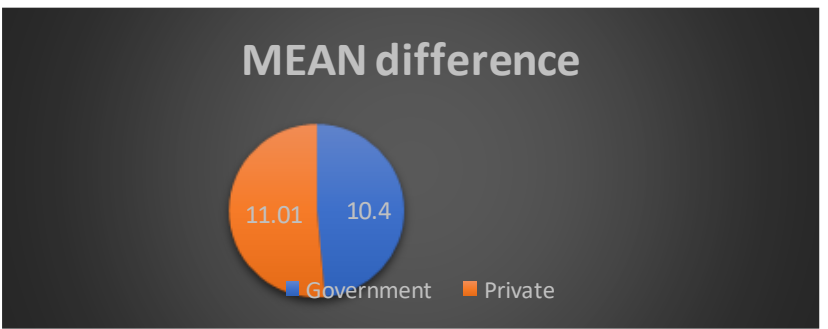

Fig IV. depicting Mean difference in the academic achievement of school students after the conduction of STEM programme.

\section{XII.ANALYSIS}

A. Analysis of table1. revealed that $72 \%$ of the male elementary schools students showed that attitude towards STEM programme is not required to improve in Maths; even $725 \%$ female elementary schools students showed that attitude towards STEM programme is not required to improve in Maths.

B. Analysis of Table 2. Shows that 6234\% male elementary students believe that STEM programme doesnot help in choosing a career in maths.; whereas only 59.84\% female elementary students believe the same.

C. Analysis of Table 3 shows that $81.2 \%$ male elementary school students believe that STEM programme helps in understanding complex Maths topics in simplified form whereas only $78.34 \%$ female elementary school students believe the same.

D. Analysis of Table 4 shows that $57.56 \%$ male elementary school students believe that STEM programme doesnot always help to score good in mathematics only $55.34 \%$ female elementary school students believe the same.

\section{FINDINGS AND DISCUSSIONS}

\section{A. After analysis of Hypothesis 1.}

-It was found that the mean of male 80.57 is very slightly more than that of female 79.65 .

- It was found that the t-value in the particular case is 0.58 .

-The p-value

\section{B. After testing of the Hypothesis 2.}

- It was concluded that the mean of female is very slightly smaller 10.65 than that of male which is 10.73 .

- The t-value came out to be 0.1576 .

\section{After testing of the Hypothesis 3.}

-It was found that the mean of private elementary school student mean is very slightly higher 80.34 than the government elementary school student mean79.65.
-The t-value came out to be -0.18 .

-The p-value came out to be .428876 which is below 0.05 than the significant level. Thus the result is not significant at .05 level.

\section{After testing of the Hypothesis 4.}

-It was found that the mean of achievement among Private elementary school students 11.01 is very slightly higher than the Government elementary school students 10.4.

-It was found that the t-value is -1.112 .

-The p-value extracted is .1333 which is clearly below 0.05 significant level. Thus, the result is not significant at .05 level.

\section{CONCLUSION}

A. From Hypothesis 1. It can be concluded that there is no remarkable distinctiveness in the attitude of students after the completion of the STEM programme in schools.

B. From Hypothesis 2. It can be concluded that There is no variation in the achievement of elementary grade students towards this new STEM program based on gender of the students.

C. From Hypothesis 3. It can be concluded that there is no significant distinctiveness in attitude of elementary students towards STEM curriculum based on school types i.e private and government schools.

D. From Hypothesis 4. It can be concluded that there is no difference in the academic and overall achievement of school students towards STEM pedagogy.

\section{REFERENCES}

1. Anderson, Gary; Nancy (1998). 'The basis of educational stategy research.'. ISBN 978-0-203-97822-1.

2. 'Teaching assessment and interdisciplinary resources'. University of Texas at Austin. September 21, 2011. The original content was archived on December 13, 2012. Searched on November 17, 2010.

3. Bybee of assessment R.W. (2010). 'Advanced STEM Education In Schools: Vision 2020'. Technical and Engineering Teacher, September 2010: 30-35.

4. R.D. Atkinson (2012). ’ Technical issues, Spring 2012: 29-36

5. Wang, H., T. J. Moore, G.H. Roehrig and M.S. Park. (year 2011) 'STEM integration: the concept and practice of teachers'. Research on college preparatory engineering education. 1 (2): 1-13.

6. Science-technology-society (STS): A new paradigm in science education. Bulletin of Science, Technology, and Society, 29(4): 287-297.

\section{AUTHORS PROFILE}

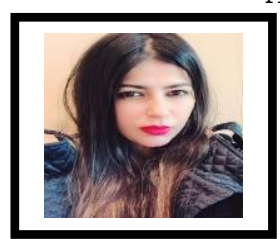

Megha chaudhary, is a research scholar who is pursuing her Ph.D in STEM Education from Amity University,Noida, India. Megha has been passionately involved in various aspects of education for over 10 years. She graduated with a Science degree from Delhi University and received 'ACADEMIC EXCELLENCE AWARD' for scoring highest marks in the college in consecutive 3 years of graduation. She gained her teacher's training degree from I.P University as a gold medalist and was awarded with Best Pupil Teacher Award. A postgraduate in Education started her teaching career in 2010.Her love for studies took her to a new dimension when she became researcher in STEM field. As a researcher she is contributing to the society by making tools for the students and schools to conduct STEM programs in schools.

Recently (2019) she is awarded with the "Most innovative Learning concept of the year Award" by Education Minister of Dethi (Maaish Sisodia). 


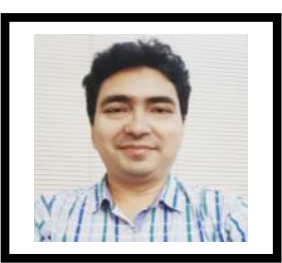

Dr. Gyanendra Nath Tiwari, M.Sc Chemistry,M.Ed. Gold Medalist ,D.Phil (Education) and UGC-JRF qualified has 18 Years of Teaching Experience at Graduate and Post Graduate Level. He is presently working as an Associate professor at Amity University, Noida and is associated with Faculty Research Committee, Board of studies, Area Advisory Board, IQAC, Ph.D. Programme, Departmental Research Committee, Amizone.Under his supervision and guidance, 4 Ph.D degrees have been awarded and 4 Ph.D are ongoing. Dr. G.N. Tiwari is been awarded by Lalloji Derawala Gold Medal in 2001 by University of Allahabad. Contributing in field of Education he has delivered Keynote address in National Seminar, Chaired Sessions in National and International Conferences and Delivered Lectures in 5 Faculty Development Programmes on various emerging issues of Education. He has Published 16 Books, 16 Research Papers in National and International Journals and 5 paper in conference proceeding and 50 Papers presented in National and International conferences/Seminars.He has also worked as Project Assistant in SIEMAT Radio Broadcast Project.He is a Member of International Advisory Board of European Academic Research, Romaniaand IATE.

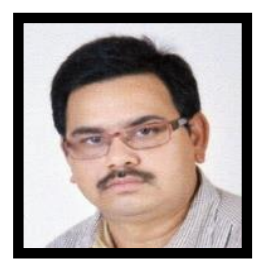

Dr.Sujeet Kumar, is working as an associate professor in department of education Guru Ghasidas Vishwavidyalya( A Central University) since March 2012.Under his guidance, 15 researches and two post doctorial researches are awarded. Four research tools developed and published by him namely family Background description index (F.B.D.I.), Mental Health Scale (MHS), Logical Thinking Test (LTT) KSTS and Feminism Reflection Inventory (FRI). Two new concepts created in the field of Education i.e. Hybrid Approach of Research and Nano Action Practice Teaching. He has generated two new theory, first Glocal Philosophy of lifestyle of Higher Education Students and second Sujeet-Amrita Indian oasis theory of feminism of Higher Education Students. Two books and 5 chapters in books are published, 36 papers are published in UGC listed international and national journals, 12 international seminar/conference papers and 62 national seminar/conference papers presented. As a Resource Person approximately 78 lectures delivered in the different parts of the country. Five times award received by him namely Best Paper Award in National workshop on Handling Research Process 2011, National Award for Innovative Researcher of the year 2013, $3^{\text {rd }}$ Cash Prize Awarded in New Education Policy and NAMODI Frame work 2016, Outstanding Faculty in Social Science 2017,Global Award 2019 for Excellence in Research.Involve in many responsibilities at department and university level. 